\title{
Markov models of territory occupancy: implications for the management and conservation of competing species
}

\author{
Pascual López-López • Alvaro Soutullo · \\ Clara García-Ripollés • Vicente Urios • \\ Luis Cadahía $\cdot$ Miguel Ferrer
}

\begin{abstract}
Markov chains have been frequently used in community ecology to model successional changes, but little attention has been paid to its application in population ecology as a tool to explore the outcomes of species interactions. Markov models can be regarded as "null models" that provide predicted values under a no-change scenario against which the consequences of changes in variables of interest can be assessed. Here we explore Markov chains' potential to project population trends of competing species and derive sensible management strategies. To do that we use six years of Weld data on territory occupancy and turn-over of two competing top predators in a Mediterranean landscape: the golden and Bonelli's eagles. The results suggest that long-term coexistence of both species in the study area is likely, with the main limitation for their coexistence being the diYculties Bonelli's eagles have in colonising new territories that become available. To avoid future declines in the population of Bonelli's eagle, it is important to take into account that the positive eVects of conservation strategies focused on encouraging colonization (e.g. decreasing disperser mortality) are likely to be larger than those focused on avoiding territory abandonment (e.g. decreasing adult mortality). Markov chains are likely to be useful to evaluate the relative
\end{abstract}

\footnotetext{
Present Address:

P. López-López (\&)

“Cavanilles” Institute of Biodiversity and Evolutionary Biology, Grupo Vertebrados Terrestres, University of Valencia, Polígono de la Coma s/n, 46980 Paterna, Valencia, Spain

e-mail:Pascual.Lopez@uv.es; lopez.pascual@gmail.com

\section{P. López-López · A. Soutullo · C. García-Ripollés · V. Urios}

Estación Biológica Terra Natura (CIBIO-Fundación Terra Natura), Universidad de Alicante, Apdo 99 E, 03080 Alicante, Spain

L. Cadahía

Departamento de Ecología Evolutiva, Estación Biológica de Doñana, Consejo Superior de Investigaciones CientíWcas, Avda. de María Luisa s/n, Pabellón del Perú, 41013 Sevilla, Spain
}

\section{Ferrer}

Departamento de Conservación de la Biodiversidad, Estación Biológica de Doñana, Consejo Superior de Investigaciones CientíWcas, Avda, de María Luisa s/n, Pabellón del Perú, 41013 Sevilla, Spain 
merit of alternative management options in other territorial species when patterns of territory occupancy are the only reliable data available, as often happens with large predators.

Keywords Aquila chrysaetos · Aquila fasciata $\cdot$ Markov chains · Null models · Raptors · Spain

\section{Introduction}

Although Markov chains have been frequently used in community ecology to model successional changes (Horn 1975; Usher 1979; Gibson et al. 1997; Wootton 2001), their application to model long-term patterns of territory occupancy of competing species is a straightforward extension of the method. Assuming that only one species can use a given territory at one time, Markov chains can be used to explore the number of territories expected to be occupied by each of two competing species in the long-term. More interestingly, they can be used to explore the consequences of changes in environmental conditions or management practices on those equilibrium values, and thus, to evaluate the likely consequences of management decisions.

First-order Markov models describe changes in populations and communities where the future value of a variable is determined by its present value but is independent of the way it is reached (Usher 1979; Caswell 2001). Thus, they can be regarded as "null models" (Gotelli and Graves 1996) that provide predicted values under a no-change scenario against which the consequences of changes in variables of interest can be assessed. Here we show that the application of simple Markov models is a useful tool to explore the consequence of management decisions on the population trends of competing species, when only data on territory occupancy are available.

The study of population dynamics of endangered or emblematic species has been a major topic of concern in conservation biology and population ecology during recent decades (e.g. Schwartz et al. 2002; Ferrer et al. 2003; Naves et al. 2003; Ontiveros et al. 2004; WhitWeld et al. 2004; Pounds et al. 2006). In spatially structured populations, the study of the conditions for species coexistence is relevant for conservation and management, as interactions with a superior competitor may lead to the competitive exclusion of competing species (Hanski 1983; Nee and May 1992; Tilman 1994; Moilanen and Hanski 1995; Palomares et al. 1996; Sergio et al. 2003; Carrete et al. 2005). Although this is an important issue to take into account when assessing the causes of populations declines, good-quality data for proper assessments are often scarce and the potential eVects of competition are rarely considered in quantitative terms.

In Mediterranean landscapes, golden eagles (Aquila chrysaetos) and Bonelli's eagles (A. fasciata) coexist sympatrically, and have been the subject of a number of studies on population dynamics (e.g. Real and Mañosa 1997; Carrete et al. 2002a; WhitWeld et al. 2004), generating intense debates among managers, ecologists and researchers about their interspeciWc relationships (Carrete et al. 2002b; Gil-Sánchez et al. 2004; Ontiveros et al. 2004). Both species are large-sized, predominantly cliV-nesting raptors, with overlapping trophic niches (Del Hoyo et al. 1994; Gil-Sánchez et al. 1994). It has often been assumed, mainly due to their larger body mass (around $4 \mathrm{~kg}$ vs. around $2.5 \mathrm{~kg}$ for Bonelli's) (Ferguson-Lees and Christie 2001), that golden eagles have superior competitive ability, reducing Bonelli's eagles' reproductive performance in areas of high densities of both species (Carrete et al. 2006), or precluding Bonelli's eagles access to otherwise vacant territories (Gil-Sánchez et al. 2004; Ontiveros et al. 2004). Although competition for both food and 
territory have been put forward (Fernández and Insausti 1990), in most cases food availability seems unlikely to be limiting, and competition is mostly expected with regards to nesting sites (Gil-Sánchez et al. 2004).

Direct usurpation and occupation of territories previously occupied by Bonelli's eagle (impeding recolonization) have been proposed as the main competition mechanisms (Cheylan 1981; Jordano 1981; Fernández and Insausti 1990; Gil-Sánchez et al. 1994; Parellada et al. 1996; Carrete et al. 2002b; Gil-Sánchez et al. 2004). In Spain, several conservation measures have been proposed to avoid Bonelli's eagles decline. These include decreasing perturbations (e.g. direct persecution) in the areas that are abandoned or remain vacant (Carrete et al. 2002a, b, 2005, 2006), controlling golden eagles populations (Carrete et al. 2002a, b), enhancing nesting site suitability for breeding, including increasing food supply (Carrete et al. 2002a, b; Gil-Sánchez et al. 2004; Ontiveros et al. 2004, 2005), reducing adult mortality (Carrete et al. 2002a, b; Gil-Sánchez et al. 2004), and decreasing the mortality of dispersing individuals (Ontiveros and Pleguezuelos 2000; Carrete et al. 2002a, 2005; Soutullo et al. 2008). These measures can be grouped into two main management strategies: (a) those aimed at decreasing juvenile mortality, and thus encouraging Bonelli's eagle colonization of new territories, and (b) those aimed at decreasing adult mortality and the abandonment of occupied territories. Here we use data on territory use to develop a Wrst-order Markovian model (Caswell 2001) to explore the potential contribution of these two strategies to ameliorate Bonelli's eagle declines in our study area.

As with other territorial top predators, surveys of territory occupancy are regularly conducted throughout most of these species ranges (e.g. Real and Mañosa 1997; Steenhof et al. 1997; Pedrini and Sergio 2002; WhitWeld et al. 2004; López-López et al. 2007a, b), with territory occupancy and turnover often being the only reliable data available to plan conservation strategies in large sectors of their range. Insights from relatively simple models like this one are likely to be more helpful for managers than uncertain predictions based on untested complex models (Hanski 1999). Such predictions, with their inevitable uncertainties are not as useful as comparisons of alternative scenarios with appropriate sensitivity analyses (see Hanski 1999 and references therein). Thus, our aim here was not to accurately predict population trajectories for these species (we acknowledge that in the long-term environmental changes will modify the observed transition probabilities, and that our estimates are not perfectly accurate), but to test the value of a simple tool to evaluate the potential contribution of alternative management decisions, based on the kind of information that is usually available for decision-makers.

\section{Materials and methods}

Species and study area

The study area comprises the Castellón province (located in the east of Spain, encompassing 6,670 $\mathrm{km}^{2}$ ) (Fig. 1). This is a typical Mediterranean landscape with habitat and climatic conditions changing from the sea level to high mountains in 40-50 km (0-1814 m asl). The annual mean temperature varies from $8^{\circ} \mathrm{C}$ in the inner highlands to $17^{\circ} \mathrm{C}$ in the coastal area with an annual mean precipitation of $400-900 \mathrm{~mm}$, the latter with high irregularity among years.

Between 2000 and 2006 we monitored all territories occupied by Bonelli's and golden eagles, as well as areas that historically had been occupied but remained vacant even though the habitat appeared suitable to either species. Observations were made with a 


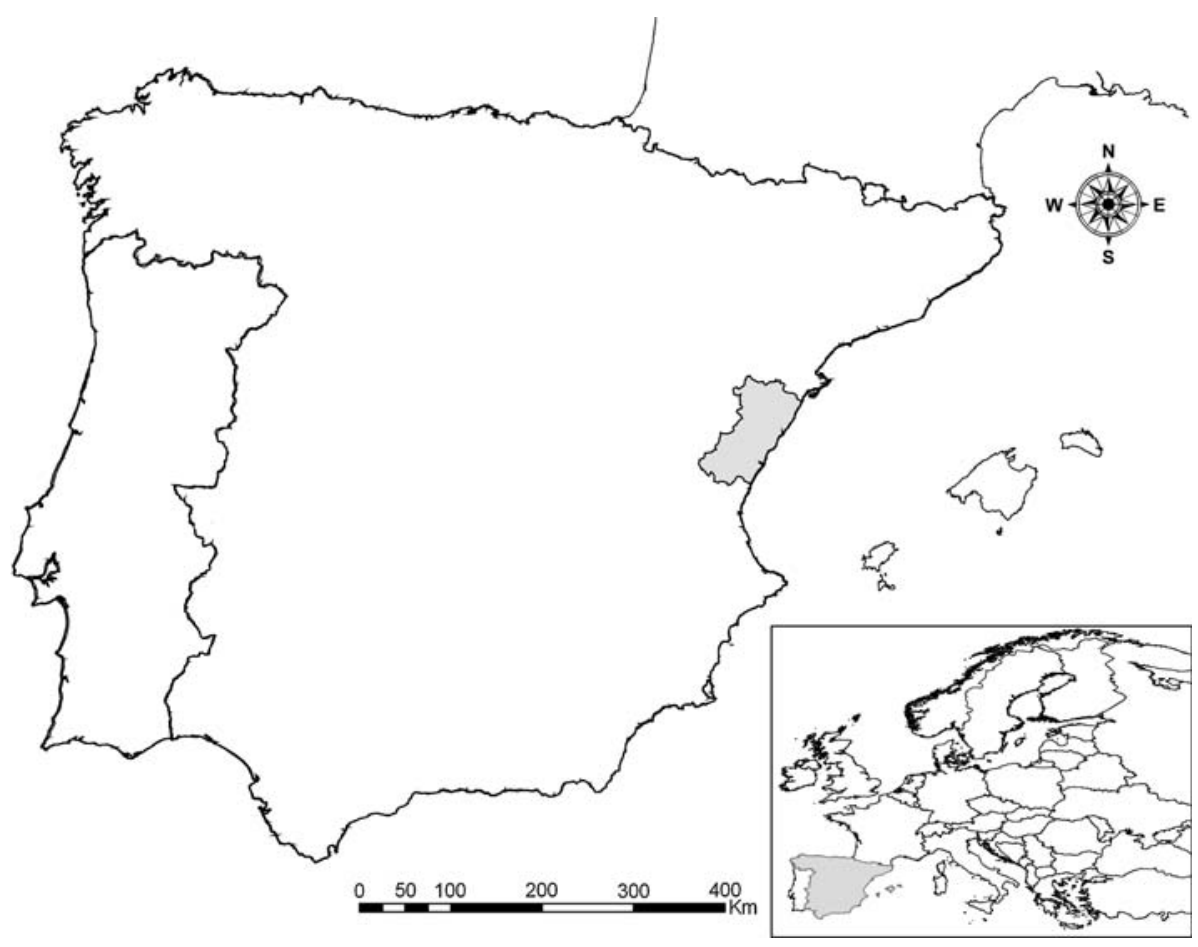

Fig. 1 The Iberian Peninsula (including Spain and Portugal) with shaded study area (Castellón province, eastern Spain). The small box shows Europe with Spain shaded in grey

20-60 £ 77 Leica Televid telescope during clear days at »300 m from nesting cliVs to avoid disturbance to eagles. A territory was considered occupied if we observed nests with green leaves, typical pair behavior such as mutual preening with close contact, courtship, brood rearing activity or young (Newton 1979; Steenhof and Kochert 1982).

The Bonelli's eagle is distributed from the European Mediterranean region to south-east Asia (Cramp and Simmons 1980; Del Hoyo et al. 1994). The Iberian Peninsula is home to approximately $80 \%$ of European breeding pairs (Del Moral 2006) and yet the species is currently considered endangered in Spain (Real 2004). After a period of decline in the mid-1980s in the Iberian Peninsula (Real and Mañosa 1997; Real 2004), Bonelli's eagle population size seems to be increasing (Del Moral 2006). The golden eagle is distributed along the Paleartic, Neartic and marginally the Indomalayan and African region (Del Hoyo et al. 1994; Ferguson-Lees and Christie 2001). The Iberian Peninsula is home to approximately 13-18\% of European breeding pairs (Arroyo 2004; BirdLife International 2004). Between 1960 and 1990 the species experienced a population decline in the Peninsula but is currently stable or even increasing (Arroyo et al. 1990; Arroyo 2004). The species is currently considered near threatened in Spain (Arroyo 2004).

\section{Construction of the Markov chain}

We calculated the frequency with which territories used by each species in a given year were occupied by the same species in the following year, colonized by the other, or abandoned, as well as the frequency with which vacant territories were colonized by either 
Table 1 Observed number of stage transitions among vacant territories or territories occupied by golden or Bonelli’s eagles, between 2000 and 2006 in Castellón province, Spain

\begin{tabular}{lccc}
\hline & \multicolumn{1}{l}{ Year $t$} & \\
\cline { 2 - 4 } & Golden & Bonelli's & Vacant \\
\hline Year $t+1$ & & & $5(0.20)$ \\
Golden & $60(0.92)$ & $0(0.00)$ & $0(0.00)$ \\
Bonelli's & $0(0.00)$ & $146(0.95)$ & $20(0.80)$ \\
Vacant & $5(0.08)$ & $7(0.05)$ & 25 \\
Total & 65 & 153 & \\
\hline
\end{tabular}

Transition probabilities are shown in brackets

golden or Bonelli's eagles, or remained unoccupied (Table 1). These frequencies were then used to calculate the transition probabilities from each stage to the others, and build the transition matrix for a Wrst-order Markov model (Usher 1979; Gotelli 2001). A Markov chain was then implemented, using the number of territories vacant or occupied by each species in 2006 as the stage vector, and a time step of 1 year. Based on habitat selection studies developed for our study area (López-López et al. 2004, 2006, 2007a), and the wide ecological plasticity in terms of selection of nesting places of both species (Cramp and Simmons 1980; Del Hoyo et al. 1994; Ferguson-Lees and Christie 2001) we assumed that all territories could be occupied by both species indistinctly, even though we recognize that both the quality of the territories and their suitability for each species might vary in the study area.

\section{Statistical analysis}

A Markov process is a stochastic process for which the values of $X_{T}$, at any set of times $t_{r}$ $(r=1,2, \ldots, n)$ are based upon the values $X_{S}$ at any set of previous times $t_{s}(s=0, \mathbf{i} 1, \ldots, \mathbf{i} j)$ (Barlett 1955). In order to check whether our data were adequate to build a Markov chain, loglinear models were Wtted to test for time-homogeneity following Hill et al. (2002). Loglinear models are more powerful than the tests developed by Anderson and Goodman (1957). Although Anderson and Goodman's tests have been used on models of ecological communities (e.g. Usher 1979; Gibson et al. 1997; Wootton 2001), the loglinear approach is more general, and can be extended to more complex experimental designs (Caswell 2001).

Sensitivity analysis

As with any matrix population model, the sensitivity analysis of a Markov model enables exploring the consequences of perturbations on the transition probabilities (Caswell 2001, 2007). This is probably the most valuable property of Markov models for the kind of questions we aim to address here, as it enables exploring the outcome of changes in environmental conditions or management practices. Nonetheless, as Markov chains require column totals to sum to 1 , it is not possible to modify only one variable while holding all others constant. This is actually an advantage for the type of questions we are addressing here because, for exploring the outcome of species interactions, it is more meaningful to explore how changes in other entries in the column compensate for changes in the variable of interest (Caswell 2001). Because we were interested in exploring the eVects of changes 


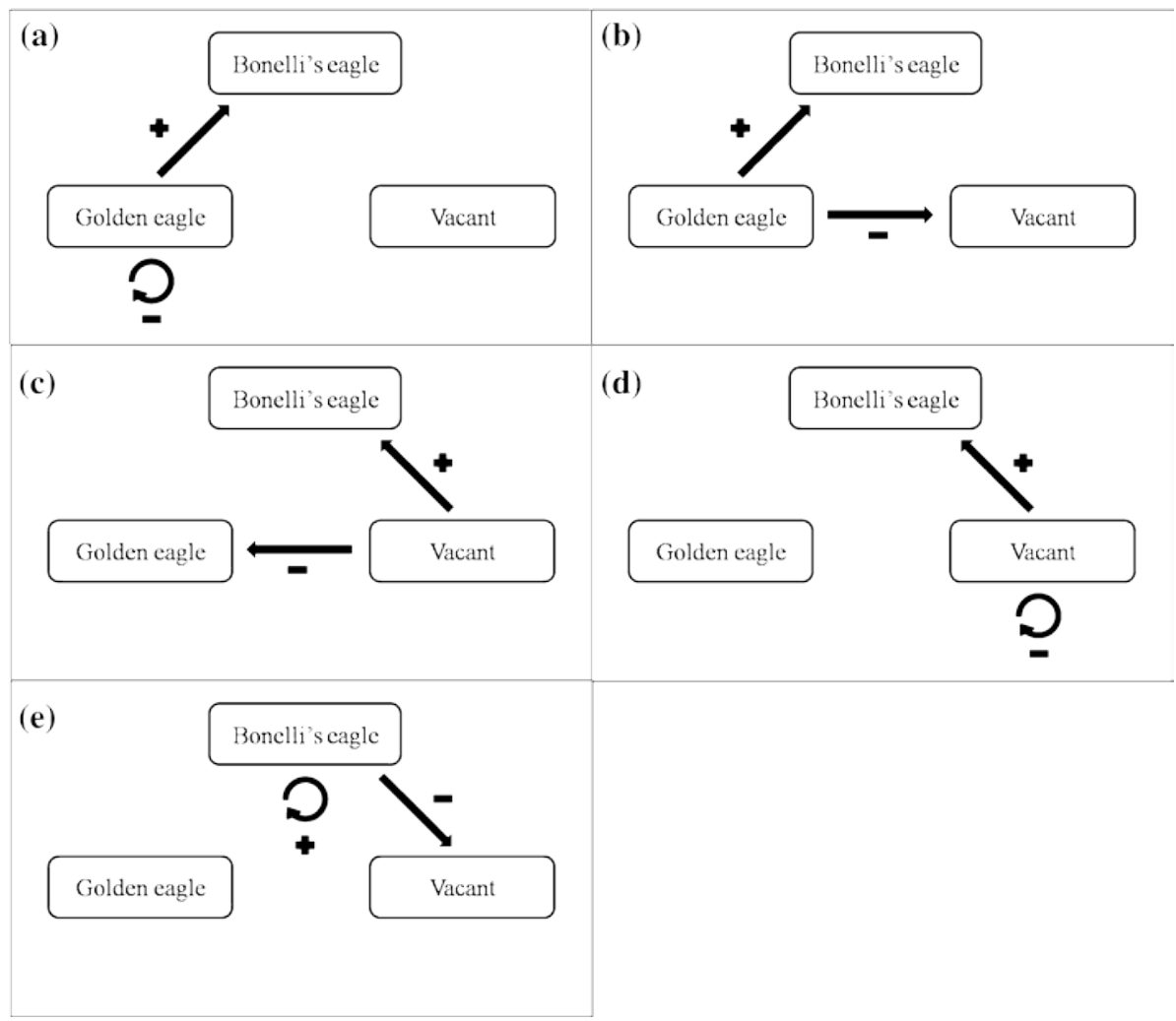

Fig. 2 Markov chain' sensitivity analysis. Increment in the probabilities of transition from vacant or golden eagles' territories to territories occupied by Bonelli's eagles in Castellón province (Spain), compensated by a corresponding decrease in the probabilities of transition to vacant or golden eagles' territories, and in the probability of territory re-use by Bonelli's eagles; $(+)$ and $(\boldsymbol{i})$ indicate an increase or decrease in the transition probability, respectively

in transition probabilities to identify management strategies that may enhance the likelihood of Bonelli's eagle population persistence (i.e., an increase in the equilibrium population size), we explored the eVects of increasing the probability of transition from vacant territories or those occupied by golden eagles, to territories occupied by Bonelli's eagles (reXecting decisions encouraging Bonelli's eagle colonization of new territories), and the eVects of increasing the probability of Bonelli's eagle territories being re-used by the species (reXecting decisions discouraging Bonelli's eagle abandonment of occupied territories). These transitions were compensated by a corresponding decrease in the frequency of either territories of golden eagles being re-used (Fig. 2a) or becoming vacant (Fig. 2b), vacant territories being colonized by golden eagles (Fig. 2c) or remaining unoccupied (Fig. 2d), or by a decrease in the frequency of Bonelli's eagles abandoning territories (Fig 2e). Thus, Fig. 2a, c reXect the outcomes of management actions aimed at controlling the golden eagle population and ensuring the availability of vacant territories for Bonelli's eagles, and Fig. 2b, d, actions aimed at increasing Bonelli's eagle colonization of vacant territories. In contrast, Fig. 2e reXects the outcomes of actions aimed at decreasing adult mortality, and discouraging Bonelli's eagle territory abandonment. 
Changes were modelled by iteratively increasing the probability of transition of the variable of interest to $1,2.5$ and $5 \%$ and consequently decreasing the compensatory variable. To further assess the relative eVect of changes in transition probabilities we calculated the number of territories occupied by Bonelli's eagles at equilibrium as transition probabilities increased from 1 to $10 \%$. This method provided a measure of how robust our conclusions were to the limitations of our Weld data (i.e., the conWdence of the transition probabilities estimated on the basis of six years of Weld observations), and most importantly, the identity of the transition probabilities whose increase would have a larger eVect on Bonelli's eagle equilibrium population size. These modelling exercises allowed us to assess which kind of territory transition (colonization or re-use), and thus, which management strategy, should be encouraged.

\section{Results}

Between 2000 and 2006 we recorded 243 territory-occupancy state transitions (Table 1). Loglinear models showed a signiWcant independent eVect of "time" $(P<0.001)$, but not of "type of transition" $(P=0.209)$ nor the interaction between "time" and "type of transition" $(P=0.992)$, allowing us to build a Wrst-order Markov chain (Table 2). This implies that the temporal variation produced parallel eVects on the transition matrices at all the territories.

If observed patterns of territory turnover persist, no territory is expected to be occupied by Bonelli's eagles by the year 2085. Yet, only 46 of the 64 territories would be occupied by golden eagles at the equilibrium, with the rest remaining vacant (Fig. 3). During the study period we did not observe any territory colonization by Bonelli's eagles. Hence, the projected decline of the Bonelli's eagle population is not surprising, as with a probability of transition from both a vacant or a golden eagle territory to a Bonelli's eagle territory of 0 , any probability of territory re-use $<1$ will eventually drive the population down to extinction. Actually, an increase to 1 and $2.5 \%$ in the probability of Bonelli's eagles re-using their territories only delayed local extinction to the years 2122 and 2191, respectively.

More interestingly, the sensitivity analysis shows that even a slight increase to $1 \%$ in the probability of Bonelli's eagles colonizing vacant or golden eagles territories is enough for species coexistence (Fig. 4a, b, c, d). Increases to 2.5 and 5\% resulted in stable coexistence with Wnal population sizes oscillating around 8-27 territories occupied by Bonelli's eagles and $24-40$ by golden eagles (Fig. $4 \mathrm{e}-\mathrm{l}$ ). Taking into account that transition probabilities are simply estimates, this suggests that under the current conditions the short and medium-term coexistence of both species in Castellón is likely, although population size might eventually decline in the long-term.

Table 2 Results of loglinear models Wtted to test the eVects of time and type of transition to build Markov chains

\begin{tabular}{lrrrr}
\hline Model & $G^{2}$ & $d f$ & $P$ & AIC \\
\hline Time & 474.960 & 48 & $<0.001$ & 378.960 \\
Transition & 52.402 & 45 & 0.209 & $\mathbf{i} 37.598$ \\
Time E Transition & 21.790 & 40 & 0.992 & $\mathbf{i} 58.210$ \\
\hline
\end{tabular}

Goodness-of-Wt values $\left(G^{2}\right)$, degrees of freedom $(d f), P$ values, and the Akaike information criteria (AIC) values calculated for loglinear models (where AIC $=G^{2}-2 £ d f$ ) are shown (more details in Burnham and Anderson 1998) 
Fig. 4 Projected changes in the number of vacant territories (dashed line) and territories occupied by Bonelli's $\mathrm{C}$ (dotted line) $(B E)$ or golden eagles (solid line) $(G E)$ in Castellón province (eastern Spain) resulting from changes in the observed transition probabilities: (a) 1\% increase in the probability of BE colonizing GE territories in the next year and 1\% decrease in the probability of GE territories becoming vacant; (b) $1 \%$ increase in the probability of BE colonizing GE territories in the next year and 1\% decrease in the probability of GE re-occupying territories; (c) 1\% increase in the probability of BE colonizing vacant territories and $1 \%$ decrease in the probability of GE colonizing vacant territories; (d) 1\% increase in the probability of BE colonizing vacant territories and $1 \%$ decrease in the probability of vacant territories remaining vacant in the next year; (e-h) the same as a-d but increasing and decreasing $2.5 \%$ the transition probabilities; (i-l) the same as a-d but increasing and decreasing $5 \%$ the transition probabilities

Finally, the maximum increase in the number of territories occupied by Bonelli's eagles does not result from the displacement of golden eagles' from their territories, but from the occupation of territories that are abandoned by golden eagles (Fig. 5). Actually, to maintain the current population size of Bonelli's eagles at around 30 pairs, it would be necessary to increase by $6-10 \%$ the probability of Bonelli's eagles colonizing territories that are abandoned by golden eagles or are currently vacant (Fig. 5). In contrast, simply decreasing the probability of Bonelli's eagles abandoning territories only delays the extinction, with only a $100 \%$ probability of territory re-use allowing coexistence.

\section{Discussion}

Application of Markov chains to conservation assessment

Markov models are simple but powerful methods for describing changes in populations and communities (Gotelli 2001). The simple model we used here does not make any inference or assumption regarding the processes regulating both species populations. Thus, this is a

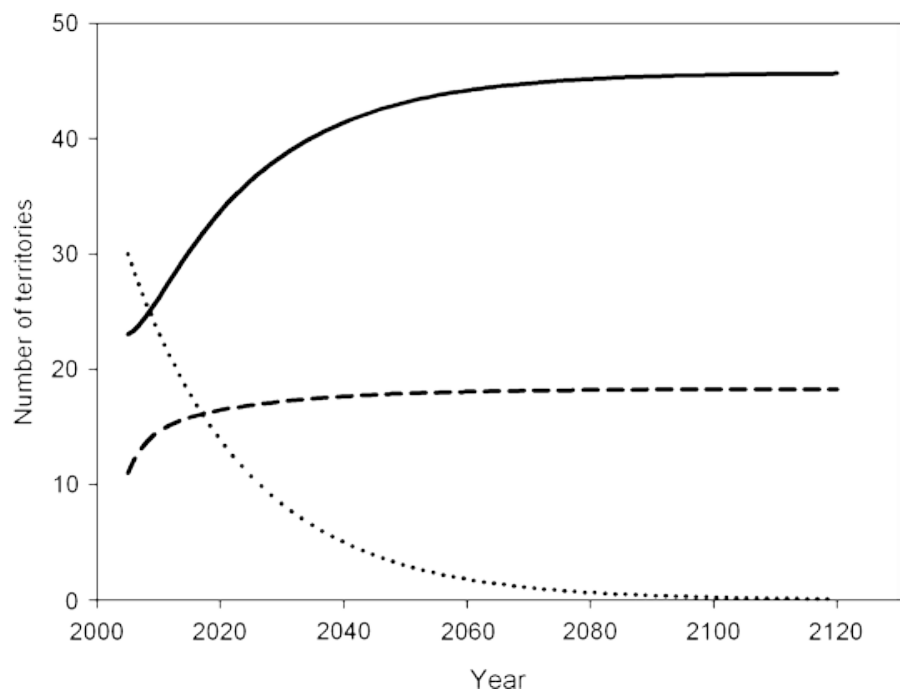

Fig. 3 Projected changes in the number of vacant territories (dashed line) and territories occupied by Bonelli's (dotted line) (BE) or golden eagles (solid line) (GE) in Castellón province (eastern Spain) resulting from territory-occupancy state transitions observed between 2000 and 2006 


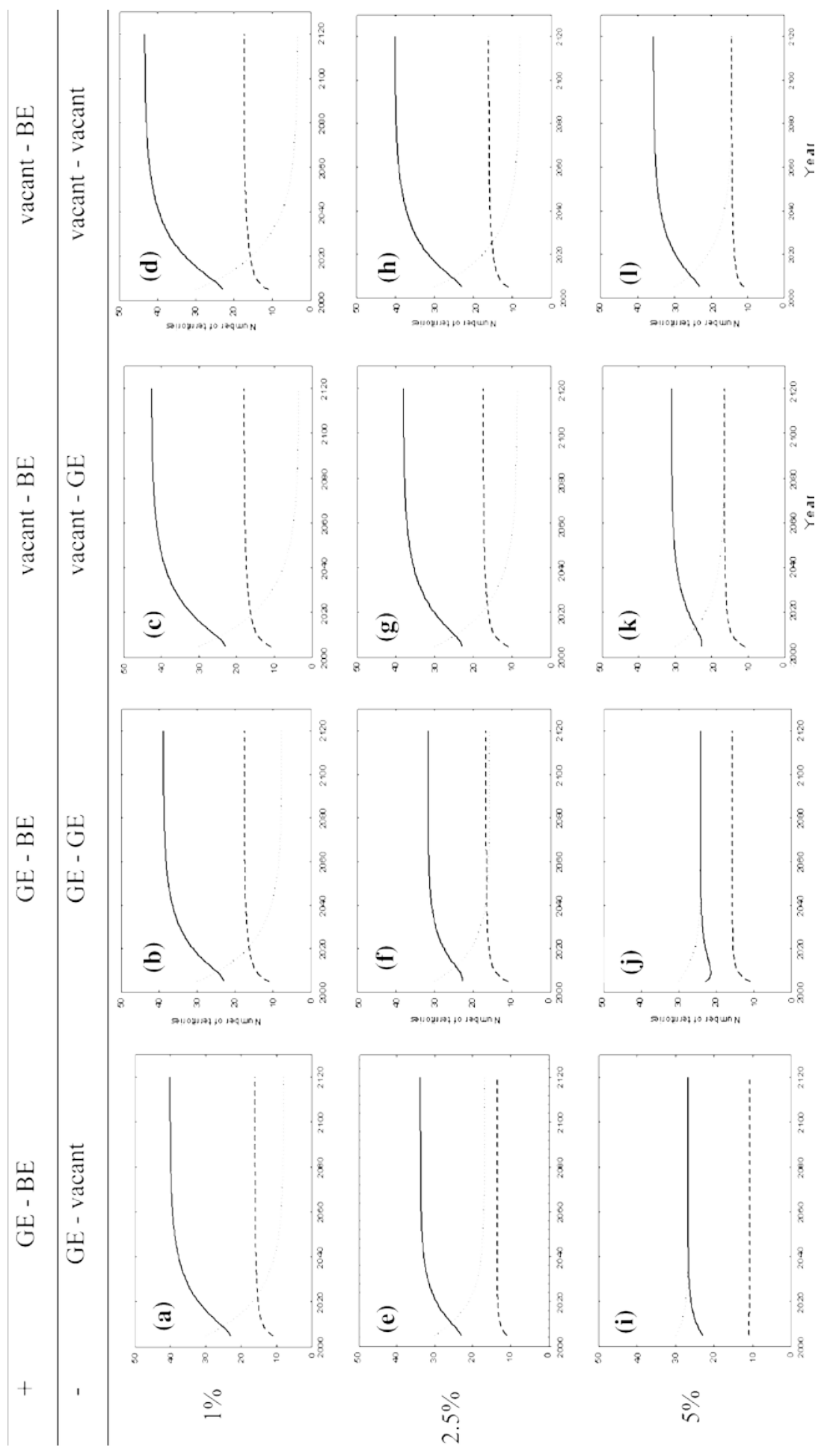




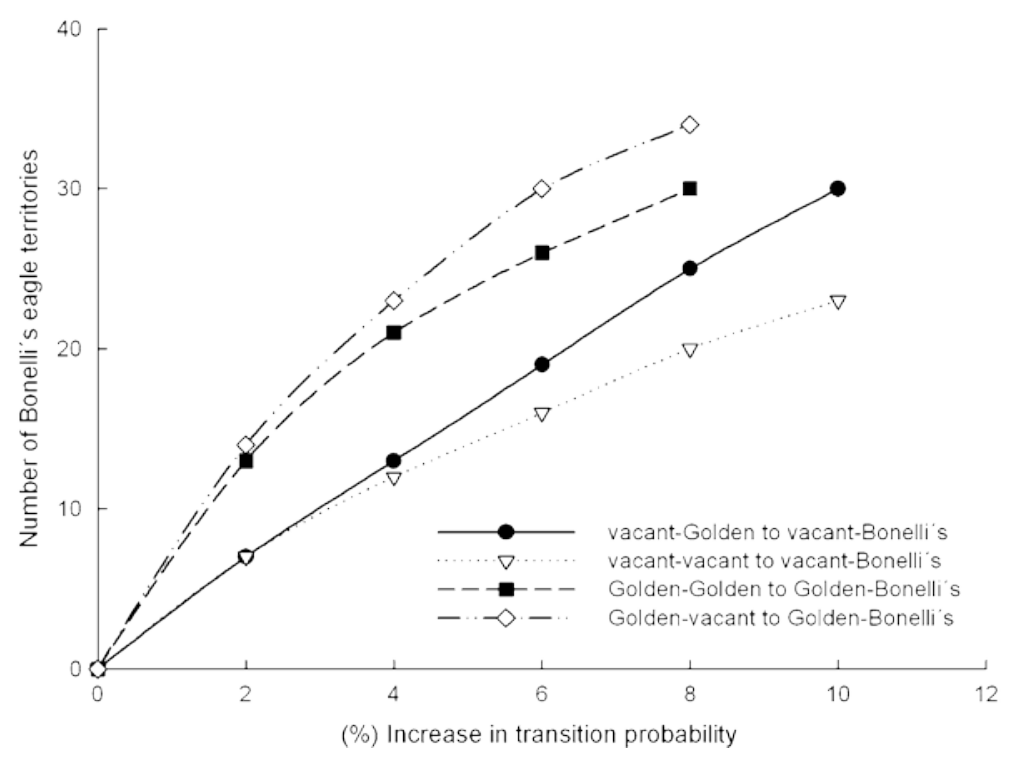

Fig. 5 Bonelli's eagles Wnal population size in Castellón province (Spain) if the probability of the species colonizing vacant territories or territories occupied by golden eagles increases, or the probability of Bonelli's eagle territory abandonment decreases (i.e., changes in transitions as those shown in Fig. 2). Note that the maximum increase in a transition probability is limited by the maximum possible decrease in the transition probability that is decreased to compensate (which cannot decrease below $0 \%$ or, conversely, it cannot exceed $100 \%)$

'black box' approach (Gotelli and Ellison 2004) that does not rely on (nor put forward) any particular mechanism of population regulation to project populations' trajectories. Yet, it assumes that the conditions that generated the observed transition probabilities will remain unchanged (or at least, that on the average the transition probabilities will remain constant). Among other assumptions this means that climatic conditions, demographic parameters, and birds' behaviour do not change, that all individuals and territories are equivalent, that there are no Xuctuations in food availability, and above all, that human-induced mortality and perturbation will not change. As such, the model is an oversimpliWcation of reality: in the long-term conditions will change.

Yet, the results, as those of most demographic analyses, are not meant to forecast what will happen, but to describe how the populations would behave if the conditions were to be maintained indeWnitely (Caswell 2001). Comparing the consequences of maintaining present conditions with those of alternative conditions reveals a great deal of biological information on populations' current circumstances (Caswell 2001). Thus, the value of Markov chains as a conservation tool does not rely on their power to accurately forecast trends in population size, but rather on its role as a null model, with predicted values under simpliWed, no-change scenarios used as benchmarks against which to compare the consequences of changes in those conditions. A distinct feature of this approach is that rather than being a theoretic description of the dynamics of the populations based on estimated demographic parameters, it uses Weld observations on territory occupancy and turnover to estimate transition probabilities and equilibrium population sizes. In this context, the most interesting property of Markov models is that sensitivity analyses can be used to explore the outcomes of changes in transitions probabilities expected under diVerent biologically plausible scenarios. Thus, 
providing a powerful, yet rarely used tool to explore the consequences of environmental changes or alternative management actions on populations.

\section{Coexistence of golden and Bonelli’s eagles}

Our Weld data suggest that for the Bonelli's eagles population to remain stable at around 30 pairs, a $6-10 \%$ increase in the observed probabilities of territory colonization is needed. The lack of records of colonization events might be simply the result of the relatively short extent of our Weld observations (6 years). Alternatively, there might be current factors hindering Bonelli's eagles' capability of settling in suitable available territories, which may eventually lead to an actual decline. The model suggests that the main reason for such a decline would be the low (in fact, null) probability of territory colonization, rather than a high probability of territory abandonment. This has important management implications.

From a conservation perspective, the most appealing management actions are those that may boost the transition probabilities with the largest positive eVect on Bonelli's eagle population size. Thus, although measures to avoid territory abandonment can have a positive eVect on Bonelli's eagle population size, they are not enough to ensure Bonelli's eagle persistence, as territory re-use can never be $100 \%$ on average. There is a need for colonization events to occur if populations are to persist (with a probability as low as $1 \%$ being enough for coexistence, as our model shows). This is not a trivial conclusion, because current eVorts to protect this species in Spain are focused on protecting adult nesting habitat. In contrast, little is done to enhance dispersing juveniles' survival, or to maintain connectivity among breeding sites, despite both processes being threatened by habitat changes due to the proliferation of wind-farms, electric power lines with dangerous pole designs, and other perilous infrastructures (e.g. Ferrer and Hiraldo 1992; Ontiveros et al. 2004; López-López et al. 2007a, b). Actually, enhancing juvenile survival has been recently demonstrated as a key factor to maintain the Bonelli's eagle population in Spain, given current conditions (Soutullo et al. 2008).

Although they are much more diYcult to implement, our model suggests that to avoid a decline in the population of Bonelli's eagle (assuming conditions remain unchanged), management strategies that encourage colonization (i.e. increasing juvenile survival) are needed, whereas strategies based solely on decreasing adult mortality and territory abandonment (such as decreasing perturbations to Bonelli's eagle territories or increasing prey availability) are unlikely to suYce. This also agrees with the Wndings of Soutullo et al. (2008) based on demographic models. Given Bonelli's eagles large dispersal distances (Cadahía et al. 2005, 2006), decreasing the mortality of dispersing individuals requires a large-scale regional management framework.

These strategies are however not antagonistic, and management actions aimed at improving one may have a positive eVect on the other. For example, improving conditions in the nesting sites might increase breeding success, but also enlarge the pool of dispersers, and hence the chance of some surviving to colonization. However, there is also a need to take into account that a possible by-product of measures to enhance breeding conditions for Bonelli's eagles (such as supplying additional food or modifying the vegetation structure), might be an enhancement of breeding conditions for golden eagles (Gil-Sánchez et al.

2004), which might increase the probability of golden eagle colonizing vacant territories. On the other hand, improving power line design will decrease both juvenile and adult mortality. Both strategies are needed and should be enforced, yet, our results (and those of Soutullo et al. 2008) suggest that without action aimed at increasing juveniles survival and the colonization of new territories, population declines are likely. 


\section{Conclusions}

Overall, we have shown that Markov chains can be a powerful tool to explore projected population trends of competing species and to evaluate the suitability of alternative management strategies. Given the availability of census data on territory occupancy in most sectors of the Iberian Peninsula, we suggest that other researchers should use this approach to explore these issues in other areas where golden and Bonelli's eagles co-exist. Furthermore, we suggest that this approach can also be useful to evaluate population trajectories and the relative merit of alternative management options of other territorial species when patterns of territory occupancy are the only reliable data available, as often occurs with large predators.

Acknowledgments Thanks are due to F. García-López and J. M. Aguilar for helping in the Weld work. The Conselleria de Territori i Habitatge of the Generalitat Valenciana provided Wnancial support to complete the monitoring of the 2005 breeding season (Project N/REF. 28/BD/05). We would like to thank especially J. Jiménez and P. Mateache for their support and personal communications. P. WhitWeld, M. Carrete and two anonymous referees made interesting comments on early drafts of the manuscript. The paper complies with the current laws of Spain. P. López-López is supported by a FPU grant of the Spanish Ministerio de Educación y Ciencia (reference AP2005-0874). This paper is a part of P. López-López Ph.D. thesis.

\section{References}

Anderson TW, Goodman LA (1957) Statistical inferences about Markov chains. Ann Math Stat 28:89-110. doi:10.1214/aoms/1177707039

Arroyo B (2004) Águila real, Aquila chrysaetos. In: Madroño A, González C, Atienza JC (eds) Red book of the birds of Spain. Dirección General para la Conservación de la Biodiversidad-SEO/BirdLife, Madrid, pp 151-153

Arroyo B, Ferreiro E, Garza V (1990) El Águila Real (Aquila chrysaetos) en España: Censo, distribución, reproducción y conservación. Instituto Nacional para la Conservación de la Naturaleza (ICONA), Madrid

Barlett MS (1955) An introduction to stochastic processesm, with special reference to methods and applications. Cambridge University Press, Cambridge

BirdLife International (2004) Birds in Europe: population estimates trends and conservation status. BirdLife International, Cambridge

Burnham KP, Anderson DR (1998) Model selection and inference: a practical information-theoretical approach. Springer, New York

Cadahía L, Urios V, Negro JJ (2005) Survival and movements of satellite-tracked Bonelli's Eagles Hieraaetus fasciatus during their Wrst winter. Ibis 147:415-419. doi:10.1111/j.1474-919x.2005.00405.x

Cadahía L, Negro J, Urios V (2006) Low mitochondrial DNA diversity in the endangered Bonelli’ s Eagle (Hieraaetus fasciatus) from SW Europe (Iberia) and NW Africa. J Ornithol 148:99-104. doi:10.1007/ s10336-006-0107-z

Carrete M, Sánchez-Zapata JA, Martinez JE et al (2002a) Predicting the implications of conservation management: a territorial occupancy model of Bonelli's eagle in Murcia, Spain. Oryx 36:349-356. doi:10.1017/S0030605302000698

Carrete M, Sánchez-Zapata JA, Martinez JE et al (2002b) Factors inXuencing the decline of a Bonelli's eagle Hieraaetus fasciatus population in southeastern Spain: demography, habitat or competition? Biodivers Conserv 11:975-985. doi:10.1023/A:1015856924451

Carrete M, Sánchez-Zapata JA, Calvo JF et al (2005) Demography and habitat availability in territorial occupancy of two competing species. Oikos 108:125-136. doi:10.1111/j.0030-1299.2005.12942.x

Carrete M, Sánchez-Zapata JA, Tella JL et al (2006) Components of breeding performance in two competing species: habitat heterogeneity, individual quality and density-dependence. Oikos 112:680-690. doi:10.1111/ j.0030-1299.2006.14528.x

Caswell H (2001) Matrix population models: construction, analysis and interpretation, 2nd edn. Sinauer Associates, Inc. Publishers, Sunderland

Caswell H (2007) Sensitivity analysis of transient population dynamics. Ecol Lett 10:1-15. doi:10.1111/j.14610248.2006.01001.x 
Cheylan G (1981) Sur le rôle déterminant de l'alimentation dans le succès de reproduction de l'Aigle de Bonelli (Hieraaetus fasciatus) en Provence. Rapaces Mediterranees I:95-99

Cramp S, Simmons KEL (1980) The birds of Western Paleartic II: hawks to bustards. Oxford University Press, Oxford

Del Hoyo J, Elliot A, Sargatal J (1994) Handbook of the birds of the world. 2. New world vultures to guineafowl. Lynx Edicions, Barcelona

Del Moral J (2006) El águila perdicera en España. Población en 2005 y método de censo. SEO/BirdLife, Madrid

Ferguson-Lees J, Christie DA (2001) Raptors: birds of prey of the world. A and C Black Pub., Ltd., London

Fernández C, Insausti JA (1990) Golden eagles take up territories abandoned by Bonelli’s eagles in Northern Spain. J Raptor Res 24:124-125

Ferrer M, Hiraldo F (1992) Man-induced sex-biased mortality in the Spanish imperial eagle. Biol Conserv 60(1):57-60. doi:10.1016/0006-3207(92)90799-S

Ferrer M, Penteriani V, Balbontín J et al (2003) The proportion of immature breeders as a reliable early warning signal of population decline: evidence from the Spanish imperial eagle in Doñana. Biol Conserv 114:463-466. doi:10.1016/S0006-3207(03)00085-5

Gibson DJ, Ely JS, Looney PB (1997) A Markovian approach to modelling succession on a coastal barrier island following beach nourishment. J Coast Res 13:831-841

Gil-Sánchez JM, Molino F, Valenzuela G (1994) Parámetros reproductivos y de alimentación del Águila real (Aquila chrysaetos) y del Águila perdicera (Hieraaetus fasciatus) en la provincia de Granada. Aegypius 12:47-51

Gil-Sánchez JM, Moleón M, Otero M et al (2004) A nine-year study of successful breeding in a Bonelli’s eagle population in southeast Spain: a basis for conservation. Biol Conserv 118:685-694. doi:10.1016/ j.biocon.2003.10.017

Gotelli NJ (2001) A primer of ecology, Third edn. Sinauer Associates, Inc. Publishers, Sunderland Gotelli

NJ, Graves GR (1996) Null models in ecology. Smithsonian Institution Press, Washington, DC Gotelli NJ,

Ellison AM (2004) A primer of ecological statistics. Sinauer Associates, Inc. Publishers, Sunderland Hanski I

(1983) Coexistence of competitors in patchy environment. Ecology 64:493-500. doi:10.2307/1939969

Hanski I (1999) Metapopulation ecology. Oxford University Press, New York

Hill MF, Witman JD, Caswell H (2002) Spatio-temporal variation in Markov chain models of subtidal community succession. Ecol Lett 5:665-675. doi:10.1046/j.1461-0248.2002.00371.x

Horn HS (1975) Markovian processes of forest succession. In: Cody M, Diamond J (eds) Ecology and Evolution of Communities. Harvard University Press, Cambridge, pp 196-213

Jordano P (1981) Relaciones interespecíWcas y coexistencia entre el Águila Real (Aquila chrysaetos) y el Águila Perdicera (Hieraaetus fasciatus) en Sierra Morena central. Ardeola 28:67-88

López-López P, García-Ripollés C, García-López F et al (2004) Distribution pattern among Golden Eagle Aquila chrysaetos and Bonelli’s Eagle Hieraaetus fasciatus in the Castellón province. Ardeola 51:275-283

López-López P, García-Ripollés C, Aguilar JM et al (2006) Modelling breeding habitat preferences of Bonelli's eagle (Hieraaetus fasciatus) in relation to topography, disturbance, climate and land use at diVerent spatial scales. J Ornithol 147:97-106. doi:10.1007/s10336-005-0019-3

López-López P, García-Ripollés C, Soutullo A et al (2007a) Identifying potentially suitable nesting habitat for golden eagles (Aquila chrysaetos) applied to “important bird areas” design. Anim Conserv 10:208-218. doi:10.1111/j.1469-1795.2006.00089.x

López-López P, García-Ripollés C, Urios V (2007b) Population size, breeding performance and territory quality of Bonelli's eagle (Hieraaetus fasciatus) in eastern Iberian Peninsula. Bird Study 54:335-342

Moilanen A, Hanski I (1995) Habitat destruction and coexistence of competitors in a spatially realistic metapopulation model. J Anim Ecol 64:141-144. doi:10.2307/5836

Naves J, Wiegand T, Revilla E et al (2003) Endangered species constrained by natural and human factors: The case of brown bears in northern Spain. Conserv Biol 17:1276-1289. doi:10.1046/j.1523-1739.2003. 02144.x

Nee S, May RM (1992) Dynamics of metapopulations-habitat destruction and competitive coexistence. J Anim Ecol 61:37-40. doi:10.2307/5506

Newton I (1979) Population ecology of raptors. T \& AD Poyser, Berkhamstead

Ontiveros D, Pleguezuelos JM (2000) InXuence of prey densities in the distribution and breeding success of Bonelli’s eagle (Hieraaetus fasciatus): management implications. Biol Conserv 93:19-25. doi:10.1016/ S0006-3207(99)00117-2

Ontiveros D, Real J, Balbontín J et al (2004) Conservation biology of the Bonelli’s Eagle in Spain: research and management. Ardeola 51:461-470 
Ontiveros D, Pleguezuelos JM, Caro J (2005) Prey density, prey detectability and food habits: the case of Bonelli's eagle and the conservation measures. Biol Conserv 123:19-25. doi:10.1016/j.biocon.2004.10.004

Palomares F, Ferreras P, Fedriani JM et al (1996) Spatial relationships between Iberian lynx and other carnivores in an area of south-western Spain. J Appl Ecol 33:5-13. doi:10.2307/2405010

Parellada X, Borau JA, Beneyeto A (1996) El águila perdicera (Hieraaetus fasciatus) en Catalunya (NE de España): estatus y plan de conservación. In: Muntaner J, Mayol J (eds) Biología y Conservación de las Rapaces Mediterráneas. Monografía no. 4. SEO/Birdlife, Madrid, pp 231-237

Pedrini P, Sergio F (2002) Regional conservation priorities for a large predator: golden eagles (Aquila chrysaetos) in the Alpine range. Biol Conserv 103:163-172. doi:10.1016/S0006-3207(01)00116-1

Pounds JA, Bustamante MR, Coloma LA et al (2006) Widespread amphibian extinctions from epidemic disease driven by global warming. Nature 439:161-167. doi:10.1038/nature04246

Real J (2004) Águila-azor perdicera, Hieraaetus fasciatus. In: Madroño A, González C, Atienza JC (eds) Red book of the birds of Spain. Dirección General para la Biodiversidad-SEO/Birdlife, Madrid, pp 154-157

Real J, Mañosa S (1997) Demography and conservation of western European Bonelli's eagle Hieraaetus fasciatus populations. Biol Conserv 79:59-66. doi:10.1016/S0006-3207(96)00100-0

Schwartz MK, Mills LS, McKelvey KS et al (2002) DNA reveals high dispersal synchronizing the population dynamics of Canada lynx. Nature 415:520-522. doi:10.1038/415520a

Sergio F, Marchesi L, Pedrini P (2003) Spatial refugia and the coexistence of a diurnal raptor with its intraguild owl predator. J Anim Ecol 72:232-245. doi:10.1046/j.1365-2656.2003.00693.x

Soutullo A, López-López P, Urios V (2008) Incorporating spatial structure and stochasticity in endangered Bonelli's eagle's population models: Implications for conservation and management. Biol Conserv 141:1013-1020. doi:10.1016/j.biocon.2008.01.011

Steenhof K, Kochert MN (1982) An evaluation of methods used to estimate raptor nesting success. J Wildl Manage 46:885-893. doi:10.2307/3808221

Steenhof K, Kochert MN, McDonald TL (1997) Interactive eVects of prey and weather on golden eagle reproduction. J Anim Ecol 66:350-362. doi:10.2307/5981

Tilman D (1994) Competition and biodiversity in spatially structured habitats. Ecology 75:2-16. doi:10.2307/ 1939377

Usher MB (1979) Markovian approaches to ecological succession. J Anim Ecol 48:413-426. doi:10.2307/4170

WhitWeld DP, Fielding AH, McLeod DRA et al (2004) Modelling the eVects of persecution on the population dynamics of golden eagles in Scotland. Biol Conserv 119:319-333. doi:10.1016/j.biocon.2003.11.015

Wootton JT (2001) Prediction in complex communities: analysis of empirically derived Markov models. Ecology 82:580-598 